\title{
Photolytical reactions for light induced biological effectors release: on the road to the phototherapeutic window.
}

\author{
Authors: C. Morville", J. Chaud", F. Bolze \& A. Specht*.
}

\begin{abstract}
:
The use of caged compounds, defined as photolabile precursors of biological effectors, have proven to be attractive in various fields of biology. Photolytical reactions have been widely used to allow a rapid and efficient concentration jump of various biological effectors within organized biological systems. During the last two decades, the challenge was to overcome the difficulty that only high energy UV light was used to induce photochemical reactions on photoremovable protecting groups (PPGs). Infrared-sensitive PPGs should be able to improve in vivo applications of caged compounds. The present review is focused on recent strategies enabling the use of excitation wavelength inside the photo-therapeutical window $(600-1000 \mathrm{~nm})$ to efficiently and specifically cleave a chemical bond.
\end{abstract}

\section{Introduction :}

Photolabile precursors of biological effectors, also called caged compounds or photocaged compounds, are molecules whose activity or function is masked by chemical modification using a photolabile protecting group (PPG) [1-4]. Light excitation of these compounds results in a rapid and specific cleavage of a chemical bond leading to a fast and localized concentration jump of the corresponding biological effectors. This strategy has been successfully used to modify the activities of various biomolecules, including peptides [5], proteins [6-7], nucleic acids [8-9], neurotransmitters [10], lipids [11] and many other biological effectors [12] in order to restore their biological functions using light. For biomedical applications, the use of photolytical reactions looks also very attractive for drug release and light controlled drug release has been achieved with PPGs or by using photoactivatable linkers [13-14]. The major drawback of most of the PPGs relies on the use of UV irradiation for the uncaging process, which is characterized by low penetration depth in living tissues and important phototoxicity. NIR sensitive PPGs are highly sought after, firstly because in the so-called photo-therapeutical window (between 600 to $1000 \mathrm{~nm}$ ) light scattering is low and there is little competing absorption from cells or tissues endogenous biomolecules, such as hemoglobin, melanin and even water [15]. Secondly, NIR radiation can minimize the photodamage to biological specimens [16]. In the last 20 years, different strategies have been explored to overcome the difficulty that only high energy light can induce photolytical reactions. In this review, the 3 main strategies for designing photoactivatable molecules or systems leading to efficient photolytical reactions using low energy excitation wavelengths will be discussed, with a particular attention for systems working in the photo-therapeutical window. The figure 1 summarizes those 3 strategies from a photophysical point of view. 


\section{One-photon visible to NIR sensitive PPGs}

One-photon photoinduced reactions using organic PPGs are needed to broadly implement the uncaging strategy for various complex biological applications. The efficiency of a PPG to specifically cleave a chemical bond using classical one-photon excitation (also called uncaging cross-section) is defined as the product of the molar extinction coefficient $(\varepsilon)$ and the quantum yield of photolytical reaction $\left(\phi_{u}\right)$. In the following paragraphs, we will describe the recent improvement performed on PPGs in the $o$-nitrobenzyl (NB), $o$-nitrophenethyl (NPE), coumarinyl, boron-dipyrromethene (BODIPY) and cyanines series. In particular, the most efficient PPGs using visible to far red excitation wavelengths will be described.

$o$-Nitrobenzyl based PPGs (see scheme 1a for its photolytical reaction pathway) have been the first used PPGs for biological applications [17-18] and have been extensively applied to control a large number of biological responses using UV excitation [2] as they can be conjugated to a large number of substrates through an alcohol, amine, phosphate, carbamate, thiol, or carboxylic acid moiety. The optimization of the uncaging efficiency for visible light excitation is extremely challenging since it is difficult to develop efficient red shifted NB PPGs. Indeed, in most cases, NB tailored with extended $\pi$-conjugation shows usually a dramatic drop of the uncaging quantum yield [19]. Recently, several strategies were investigated to induce a bathochromic shift of the NB scaffold absorbance and to allow an efficient photolytic reaction upon one-photon excitation. In 2014, Abe, Katan and Kobayashi developed a dialkyl-dihydronaphthalene NB derivative for the release of glutamate neurotransmitter (1 in scheme 4) [20]. This latter compound showed an absorbance maximum around $440 \mathrm{~nm}$ and was able to release glutamate with an uncaging efficiency of $60 \mathrm{M}^{-1} \mathrm{~cm}^{-1}$. In 2016, the group of Ellis-Davies developed a bis-styrylthiophene (BIST) NB derivative with an absorption maximum at $440 \mathrm{~nm}$, and was used to develop a photocleavable caged $\mathrm{Ca}^{2+}$ chelator ( 2 in scheme 4) with a high uncaging efficiency of $15180 \mathrm{M}^{-1} \mathrm{~cm}^{-1}$ [21].

In 2012, our group succeeded to design efficient PPGs in the $o$-nitrophenethyl serie (see scheme $1 \mathrm{~b}$ for its photolytical reaction pathway). Dialkylamino-biphenyl NPE based PPGs were therefore described for the release of the GABA neurotransmitter (3 in scheme 4) taking advantage of the dialkylamino group which enables functionalization with oligoethylene glycol/carboxylic acid moieties to improve water solubility [22]. Those compounds showed an absorbance maximum around $397 \mathrm{~nm}$ and were able to release GABA with an uncaging efficiency of $1125 \mathrm{M}^{-1} \mathrm{~cm}^{-1}$. In 2014, Wombacher introduced a NPE based PPG by introducing an alkyne linkage on the dialkylamino-biphenyl platform for the development of caged gibberellic acid (4 in scheme 4). This modification led to a PPG with a $413 \mathrm{~nm}$ absorbance maximum and an uncaging efficiency of $2500 \mathrm{M}^{-1} \mathrm{~cm}^{-1}[23]$.

Coumarin-based PPGs (see scheme 1c for the photolytical reaction pathway) have been recently applied to the release of a large number of biological effectors due to ease of synthesis and their rapid photolytical reactions (in the ns range) [24]. This scaffold allows to couple a large number of substrates through a carbonate, carbamate, phosphate, pyridine, or carboxylic acid moiety [25]. In the last seven years, many efforts have been performed to build red shifted 7-(diethylamino)-4-(hydroxymethyl)coumarin (DEAC) PPGs. Therefore, dipolar DonorAcceptor $\pi$-system and quadripolar Donor-Donor $\pi$-system have been developed. In 2013, the group of Jullien synthesized a series of such coumarin scaffolds with electron donating group $\left(\mathrm{OMe} / \mathrm{NEt}_{2}\right)$ at the 7-position and different electron withdrawing groups at $2 / 3$ positions aimed at extending the $\pi$-conjugation of the system [26]. In particular, this research group was able to develop a coumarin analog bearing thiocarbonyl group at the 2position for the uncaging of a non-endogenous Cyclofen-OH gene expression inducer [27]. This caged compound (5 in scheme 4) showed an absorption maximum at $492 \mathrm{~nm}$ with an uncaging efficiency of $58 \mathrm{M}^{-1} \mathrm{~cm}^{-1}$. Of note, the empty $3 \mathrm{~d}$ orbital of the sulfur atom of the thiocarbonyl group is expected to enhance the intramolecular charge transfer (ICT) process leading to an increase in the absorbance maximum of this DEAC analog. In 2013, the EllisDavies group also modified the DEAC scaffold and introduced a vinyl acrylate function in the 3-position leading to the so called DEAC450 chromophore [28]. This red shifted PPGs was used to liberate glutamic acid (6a in scheme 4) and showed an absorbance maximum at $450 \mathrm{~nm}$ with an uncaging efficiency of $16800 \mathrm{M}^{-1} \mathrm{~cm}^{-1}$. In 2017 , the group of Ellis-Davies was able to use this interesting PPG to liberate the GABA neurotransmitter and to effectively reduces the antagonism effect of this later caged-GABA $\mathbf{6} \mathbf{b}$ to a very low level by the conjugation of a large and neutral propargyl-[G5]-(OH) 32 bis-MPA dendron [29]. In 2016, Katan and Abe groups explored the effect of a Donor-Acceptor system leading to a 7-methoxy-coumarin derivative substituted at the 3 position by a electro withdrawing $p$-nitrophenyl group, this PPG was able to release benzoic acid (7 in scheme 4) and showed an absorbance maximum at $345 \mathrm{~nm}$ with an uncaging efficacity of $2045 \mathrm{M}^{-1} \mathrm{~cm}^{-1}$ [30]. In 2017, the same group also developed Donor-Donor $\pi$-system, therefore the DEAC PPG was modified by an aminophenyl appendage at the 3-position ( 8 in scheme 4) leading to PPG with an absorption maximum at $407 \mathrm{~nm}$ and an uncaging efficiency of $4560 \mathrm{M}^{-1} \mathrm{~cm}^{-1}$ [31]. In 2018, Zhu's group synthesized DEAC analogues with electron rich styryl appendages in 
3-position [32] inducing red shifted absorption maxima at 446 and $515 \mathrm{~nm}$, and uncaging efficiencies up to 8200 and $17500 \mathrm{M}^{-1} \mathrm{~cm}^{-1}$ for $\mathbf{9}$ and $\mathbf{1 0}$ respectively (scheme 4). Of note, the styryl appendage also allowed to produce an unconjugated by-product through an intramolecular reaction on the light generated carbocation (see Scheme 2). This nice improvement lead to the disappearance of the competitive absorption by the photolysis sub-products (sub-product photobleaching). In 2019, the group of Kele introduced modified DEAC PPGs with pyridinium and benzothiazolium heterocycles in 3-position. Compound 11, 12 and $\mathbf{1 3}$ showed absorption maxima at 482, 493 and $538 \mathrm{~nm}$ respectively with uncaging efficiencies of 260,335 and $57 \mathrm{M}^{-1} \mathrm{~cm}^{-1}$ respectively [33]. The same year, the group of Blanchard-Desce also appended Donor-Acceptor $\pi$-system at the 3-position of the DEAC PPGs in order to develop caged glycines. The incorporation of respectively a vinylthiazole (14 in scheme 4), a 2vinylbenzo[d]thiazole (15a in scheme 4), an elongated fluorenyl-2-vinylbenzo[d]thiazole (15b in scheme 4), a 2vinylbenzo[d]oxazole (16 in scheme 4) and a 4-vinylbenzo[c][1,2,5]thiadiazole group (17 in scheme 4) led to absorption maxima at 457, 472, 458,467 and $472 \mathrm{~nm}$ respectively and uncaging efficiencies of 7800, 4000, 18.900, $4500 \mathrm{M}^{-1} \mathrm{~cm}^{-1}$ and below of $600 \mathrm{M}^{-1} \mathrm{~cm}^{-1}$ respectively [34].

C4'-dialkylamine-substituted variants of the heptamethine cyanine (see scheme 3 for photolytical reaction pathway) have been reported in 2014, as PPGs by the group of Schnermann [35]. They demonstrated that cyanine derivatives like compound $\mathbf{1 8}$ are able to perform light assisted chemical bond cleavage via a regioselective photooxidative polyene reaction using a $690 \mathrm{~nm}$ excitation wavelength. This scaffold was used in combination with a self-immolative linker to uncage a non-endogenous Cyclofen-OH gene expression inducer.

The same year, Urano's group discovered that the well-known BODIPY fluorophore could be used as a PPG and postulate that the bound cleavage was triggered by a photoinduced electron transfer (PeT)-based process [36]. Classical BODIPYs have an absorption maximum at $502 \mathrm{~nm}$ and photocleavage enables the release of phenol function with an uncaging efficiency below to $60 \mathrm{M}^{-1} \mathrm{~cm}^{-1}$. This research group developed caged histamine using a BODIPY PPG (19). In 2015, further studies were described on a meso-methyl-hydroxy-BODIPY (see scheme $1 \mathrm{~d}$ for photolytical reaction pathway) connected either directly or via a carbamate linker to biological effectors. First, the group of Weinstain developed a caged- $p$-nitrobenzylamine (20a), a caged-histamine (20b) and a caged dopamine (20c) using a meso-methyl-hydroxy-BODIPY. Compound 20a showed an absorbance maximum at 545 $\mathrm{nm}$ and an uncaging efficiency of $7 \mathrm{M}^{-1} \mathrm{~cm}^{-1}$ [37]. Secondly, the group of Winter was able to photorelease acetic acid using the BODIPY derivative 21, and this latter compound showed an absorption maximum at $553 \mathrm{~nm}$ with an uncaging efficiency of $117 \mathrm{M}^{-1} \mathrm{~cm}^{-1}$ [38]. In 2017, Klán, Weinstain and Winter groups were able to dramatically increase BODIPY's uncaging efficiencies by systematic structure-activity relationship studies [39]. In particular, they demonstrated that iodo-BODIPYs are able to increase the uncaging quantum yield and they introduced the BODIPY caged phenylalanine analog 22. This latter showed an absorption maximum at $537 \mathrm{~nm}$ with an uncaging efficiency of $20150 \mathrm{M}^{-1} \mathrm{~cm}^{-1}$. In 2018, the group of Winter added strong electron-donating groups to a mesomethyl-hydroxy-BODIPY. This red shifted BODIPY derivative was chemically modified by two styryl linkers and benzyl alcohol was used as leaving group via a carbonate linkage. The authors were able to demonstrate that the caged benzyl alcohol 23 had an absorbance maximum at $693 \mathrm{~nm}$ with an uncaging efficiency of $73 \mathrm{M}^{-1} \mathrm{~cm}^{-1}$ [40]. BODIPY PPGs exhibit very interesting absorbance wavelengths that now fall in the transparency window enabling more sophisticated biological applications of the uncaging concept. However, the uncaging efficiency need to be improved. Some recent work performed by the group of Peifer, has also pointed out that the uncaging mechanism and his efficiency can be limited in an aqueous environment due to a competitive production of singlet oxygen upon irradiation [41].

Exciting recent progress, particularly using the Coumarinyl, the BODIPY and the cyanine scaffolds, has extended the uncaging concept in wavelengths well into the visible range, but other strategies are still needed to efficiently cleave a chemical bound in the 650-1000 nm region.

\section{Efficient two-photon sensitive NIR PPGs:}

In order to overcome the difficulty that only high energy light can efficiently induce a photolytical reaction, a second strategy based on the use of two-photon induced photolysis was developed during the last 20 years (Figure 1 center). After the first report of two-photon uncaging by the group of Tsien in 1999 [42], this technique has become well established over the last years as an alternative to classical one-photon excitation for triggering PPGs photolysis [43-45]. In Two-Photon Excitation (TPE), a chromophore will not reach an excited state by absorption of one photon with the energy $E=h v$, but by the simultaneous absorption (within $<1 \mathrm{fs}$ ) of two photons of half the energy $E^{\prime}=h v / 2$ (Figure $1 \mathrm{~b}$ ). After excitation, it is assumed that the chromophore, i.e. the PPG, undergoes the same photolytic steps as with conventional one-photon excitation [43-46]. TPE is based on a non- 
linear process, and the probability for TPE to occur scales with the squared light intensity. Due to this quadratic dependency, the excitation will be possible only with very high light intensities, out of range of classical sources used for one-photon excitation. This technique indeed requires the use of pulsed (fs range with high peak power in the range of $10^{8} \mathrm{~W} . \mathrm{cm}^{-2}$ ) focalized lasers, inducing a temporal and spatial concentration of photons reaching the molecules. As a consequence, TPE and can only occur in a very small 3D volume surrounding the focal point of the optical system. This volume can be as small as $1 \mu \mathrm{m}^{3}$ for a tightly focused laser and no excitation occurs outside the focal volume, in contrast to a single photon process were all the light pathway is excited.

The efficiency of a PPG to specifically cleave a chemical bound using two-photon excitation $\left(\delta_{\mathrm{u}}\right)$ is defined as the product of the two-photon absorption cross section $\left(\delta_{\mathrm{a}}\right.$ expressed in GM) and the uncaging quantum yield of photolytical reaction $\left(\phi_{u}\right)$. In 2001, the first biological application of TP uncaging was reported by Kasai and co-workers using 24 4-Methoxy-7-NitroIndolinyl or MNI caged glutamate (see scheme 1e for photolytical reaction pathway) $\left(\delta_{\mathrm{u}}=0.06 \mathrm{GM}\right.$ at $\left.730 \mathrm{~nm}\right)$. In particular, they were able to mimic a neurotransmitter's release at single synapse resolution using $730 \mathrm{~nm}$ TPE [47]. This work initiated the development of specific PPGs with larger molecular two-photon cross-sections.

Since the two-photon absorption cross-section of a chromophore relies mostly on its molecular structure as well as its environment, many efficient UVA or blue light sensitive PPGs have therefore been embedded within conjugated di-polar, quadrupolar or octopolar architectures in order to improve their two-photon absorption properties for 720 to $950 \mathrm{~nm}$ excitations (Sheme 5) [43-45].

In this context, our group developed a new generation of PPGs for the release of carboxylic acids with TP uncaging efficiencies up to $11 \mathrm{GM}$. Compounds of this new generation have been successfully applied to the photo-controlled release of the neurotransmitters $L$-glutamate [48] and GABA [22] in intact neuronal tissue at respectively $720 \mathrm{~nm}$ and $800 \mathrm{~nm}$ using 25 and 3. Starting from these contributions we will focus on the developments in the field of TP uncaging from the last eight years.

The extension of the aromatic system is one of the rational ways to upgrade two-photon properties of a compound. This was remarkably performed in 2014, by Abe, Katan and Kobayashi groups, using a dialkyl-dihydro naphthalene NB derivative for the release of the Glutamate neurotransmitter 1 who showed an important TP uncaging action cross-section of $\sim 1.2 \mathrm{GM}$ at $680 \mathrm{~nm}$ [20]. The same groups were able in 2016 to develop two caged calcium chelator (26a, 26b and 27) with respectively an TP uncaging action cross-section of 16 GM at 740 $\mathrm{nm}$ [49], 20.7 GM at $740 \mathrm{~nm}$ [49] and 7.8 GM at 800nm [50]. The same year, the group of Ellis-Davies reported the BIST-NB caged $\mathrm{Ca}^{2+}$ chelator (2) who showed an impressive TP uncaging action cross-section of $\sim 80 \mathrm{GM}$ at $775 \mathrm{~nm}[21]$.

The two-photon sensitivity of Quinoline PPGs (see scheme 1f for its photolytical reaction pathway) have also been increased in 2014 by the group of Dalko. New quadrupolar species, where two quinolines moieties were directly linked in two different positions, have led to caged acetic acids $\mathbf{2 8}$ and $\mathbf{2 9}$ reaching respectively $\delta_{\mathrm{u}}=0.07$ GM and $0.40 \mathrm{GM}$ at $730 \mathrm{~nm}$ [51]. In 2015, the group of Dalko reached a TP uncaging cross-section of $\delta_{\mathrm{u}}=2 \mathrm{GM}$ at $730 \mathrm{~nm}$ for compounds $\mathbf{3 0}$ by identifying the C5-substituted isomer as a privileged isomer to increase the twophoton sensitivity of 8-dimethylaminoquinoline derivatives [52]. In 2017, the group of Dalko reported two multipolar Quinoline PPGs with $\delta_{\mathrm{u}}$ values respectively of $0.3 \mathrm{GM}$ at $730 \mathrm{~nm} 2.3 \mathrm{GM}$ at $730 \mathrm{~nm}$ and for compounds 31 [53] and 32 [54]. In 2020, the group of Dore reexplored the 8-cyano-7-hydroxyquinolin-2-ylmethyl (CyHQ) PPG [55] by introducing several electron withdrawing or donating groups at the $\mathrm{C} 4$ position. Compounds 33 a-f were used to mediate an efficient release of homopiperonylic acid with remarkable $\delta_{\mathrm{u}}$ values (up to $2.64 \mathrm{GM}$ ) and excellent one photon quantum yields (up to 0.88) [56].

Coumarinyl PPGs have also been extensively optimized to upgrade their two-photon properties. In 2013, the Ellis-Davies reported the DEAC450 PPGs with a TP uncaging action cross-section of 0.5 GM at $900 \mathrm{~nm}$ [28]. Katan and Abe groups reported a 7-methoxycoumarin and DEAC analogs modified respectively with an nitrophenyl or a aminophenyl appendage at the 3-position (7 and 8). This modification led to a TP uncaging action cross-section of respectively 3.4 GM at 710nm [29] and $1.1 \mathrm{GM}$ at $750 \mathrm{~nm}$ [30]. In 2018, the Zhu group synthesized the DEAC analogue 9 with electron rich styryl appendages at the 3-position [31]; this latter PPG showed a TP uncaging action cross-section of $39.6 \mathrm{GM}$ at $730 \mathrm{~nm}$. Finally, Kele [32] and Blanchard-Desce [33] groups introduced, in 2019, various donor systems at the 3-position of the DEAC PPGs leading to Coumarinyl PPGs with TP uncaging action cross-section summarized in table 1 . In particular, the caged compound $\mathbf{1 5 b}$ showed an unprecedented uncaging action cross-section of $442 \mathrm{GM}$ at $730 \mathrm{~nm}$ !

In summary, the increase of the two-photon absorption sensitivity by molecular engineering led to highly efficient TP sensitive PPGs (up to 440 GM uncaging cross-section for compound 15b). However, it is extremely difficult to predict how this strategy will influence the uncaging quantum yield [19,57]. Therefore, a second strategy was described for the rational design of TP sensitive PPGs. This strategy called sensitized uncaging, is based on the use of TP sensitive moieties as an antenna to transfer the light energy to a PPG. It has been reviewed, 
in 2019, by the group of Blanchard-Desce [58]; therefore in this review we decide to present only the most efficient systems.

In 2013, a very efficient 2P sensitive modular system was described by Anderson and Blanchard-Desce groups. A pyridinium based PPG (see scheme $1 \mathrm{~g}$ for his photolytical reaction pathway) able to liberate carboxylic acid functions by photoinduced electron transfer (PeT) was coupled to a symmetric banana-shaped bisethynylfluorene (BEF) (in which the core is extended with substituted anilines via acetylene bridges) TP antenna dye. This complex system led to the synthesis of the caged GABA 34, who showed an important TP uncaging cross-section of $10 \mathrm{GM}$ at $700 \mathrm{~nm}$ [59]. In 2016, the group of Blanchard-Desce was able to increase the TP sensitivity of the MNI PPG using a tandem system which a TP absorbing module linked to the PPG via a phosphorous clip, that act together by Forster Resonance Energy Transfer (FRET). This strategy led to a caged acetic acid 35 with a TP uncaging cross-section of $20 \mathrm{GM}$ at $710 \mathrm{~nm}$ [60].

Many PPGs have been reported with increased TP uncaging efficiencies by several organic chemistry groups leading to TP uncaging efficiencies up to $440 \mathrm{GM}$. However, for biomedical applications two-photon absorption is a time-consuming spot-by-spot process to expose macroscopic materials like tissues or organs [3]. These features have recently stimulated the needs of in situ nanotransducers that can generate UV or visible light with a lowenergy NIR excitation.

\section{NIR Upconversion assisted photolysis}

NIR to UV (or visible) upconversion (UC) processes have been recently used to assist photolytical reactions. The UC process has been established since the 1960s to generate anti-Stokes shift luminescence [61]. This process relies on the existence of multiple intermediate states to accumulate low-energy excitation photons. Those systems are able to absorb energies from two or more photons subsequently and to generate one emission photon with higher energy. This latter emission can be transferred to a PPG in order to induce a photolytically reaction using low energy excitation (Far red or NIR excitations). UC process can take place in organic and inorganic materials and many high brightness upconversion systems have been reported in nanomaterials [62]. The process of UC is mediated by real electronic states, while in TP excitation real intermediate electronic states do not take part. Due to this difference, the TP excitation based on simultaneous interaction of two photons require $5-10$ orders of magnitude higher excitation powers but yield more than 5 orders of magnitude lower quantum efficiency in comparison to UC [63]. The intermediate states involved in UC must be excited, therefore material systems where these states have relatively long lifetimes will increase the probability of interaction with subsequent photons. This condition is met by quantum systems with parity-forbidden, but partly allowed optical transitions. Therefore lanthanide (Ln) doped materials are most frequently investigated in the context of UC $[64,65]$.

In 2010, the group of Branda was able to spectroscopically demonstrate that UC assisted photolysis can be performed on a 3',5'-dialkoxybenzoin PPG using a core-shell lanthanide-doped $\mathrm{NaYF}_{4}: \mathrm{TmYb}^{2}$ nano-particles and an $980 \mathrm{~nm}$ excitation $\left(550 \mathrm{~W} . \mathrm{cm}^{-2}\right)$ [66].

In 2012, Lin and Xing groups, have successfully been able to perform an UC assisted photolysis of an $o$ nitrobenzyl caged D-luciferin. In this nice work a $\mathrm{Tm} / \mathrm{Yb}$ co-doped $\mathrm{NaYF}_{4}$ core-shell nanoparticles that have a reduced surface-quenching effect was selected as the platform for the conjugation of D-luciferin using an NB linker (see Figure $2 \mathrm{c}$ ). In vivo bioluminescence experiments on mice were performed and strong bioluminescence signals were detected on mice that were injected with the caged D-luciferin/UC nanoparticle conjugate after $1 \mathrm{~h}$ of $980 \mathrm{~nm}$ excitation (at $255 \mathrm{~W} \mathrm{~cm}^{-2}$ ) [67].

In 2011, Branda and Zhao groups, were able to use $\mathrm{NaYF}_{4}: \mathrm{TmYb}$ UCNPs inside micelles formed by $o$ nitrobenzyl caged poly(ethylene oxide)-block-polymethacrylate. An UC assisted photolysis (using $980 \mathrm{~nm}$ light) was used to cleave the $o$-nitrobenzyl groups and to convert the polymethacrylate block into an hydrophilic poly(methacrylic acid), which shifts the hydrophilic hydrophobic balance toward the destabilization of micelles. This system was therefore able to perform a light induced dissociation of the micelles and the release of co-loaded hydrophobic species leading to a nice NIR controlled drug release NP (see Figure 2 a) [68]. In 2012, the same research groups had described a similar drug release strategy based on NB caged hydrogels. This photosensitive hybrid hydrogel loaded with UCNPs, showed that NIR light $(980 \mathrm{~nm})$ can induce a gel-sol transition leading to the release of inactive biomacromolecules entrapped in the hydrogel (see Figure 2 a) [69]. In 2014, Wu and coworker used UCNPs with a mesoporous silica shell to improve the NIR controlled drug release on NP. A mesoporous silica shell was used to release an anticancer drug doxorubicin using NIR light. Therefore, Ru PPGs were drafted onto the NP surfaces. The Ru complexes acted as molecular valves, which prevented drug leakage 
(see Figure 2 b). Upon NIR irradiation, UC assisted photolysis enabled to release the drug which inhibited cancer cells growth. Of note, this system allowed to use a relatively low $980 \mathrm{~nm}$ excitation $\left(0.35 \mathrm{~W} \mathrm{~cm}^{-2}\right)$ [70]. In 2013, $\mathrm{Zhu}$ and Li were able to release the anticancer drug chlorambucil using a hydrophobic 7-aminocoumarin PPG and a yolk-shell structured $\mathrm{NP}$ (coating of the $\mathrm{NaLuF}_{4}$ shell on the $\mathrm{NaYF}_{4}: \mathrm{Yb}, \mathrm{Tm}$ core) after $980 \mathrm{~nm}$ excitation (50 $\mathrm{mW} \mathrm{cm}^{-2}$ ) in a living animal model [71].

In 2013, Su and Yeh groups, were able to use UC assisted photolysis to activate a caged species in order to control cell targeting groups on UCNPs' surfaces. A tumor-homing agent folate was modified with an $o$ nitrobenzyl PPG and grafted onto UCNPs. Upon NIR irradiation $(980 \mathrm{~nm})$, the UC assisted photolysis allowed folate-conjugated UCNPs to target cancer cells [72] leading to a NIR controlled targeting of the NP. This concept was improved in 2014 by Qu and co-workers who introduced UCNPs grafted with photocleavable NB linker bearing an arginine-glycine-aspartic acid (RGD) bioadhesive ligand. This latter UCNP has been successfully used to control cell adhesion using a $980 \mathrm{~nm}$ light excitation $\left(2-4 \mathrm{~W} \mathrm{. \textrm {cm } ^ { - 2 } )}\right.$ by UC assisted photolysis on an $o$-nitrobenzyl linker [73].

Several other UC assisted photolytical reaction using Lanthanide ion-doped inorganic crystals have already been described [74-77]; but up to date, all those UCNPs still suffer from high power excitation requirement $\left(10^{2}-10^{-1} \mathrm{~W} . \mathrm{cm}^{-2}\right)$ and inherently poor UC quantum yields.

Therefore, alternative UC strategies have recently been investigated, particularly using organic chromophore-based systems that achieve efficient triplet-triplet annihilation (TTA)-based UC [78,79]. Those latter UCNPs should allow to perform efficient photolytical reactions using low power NIR excitations in a near future.

\section{Conclusion :}

Photolabile precursors of biological effectors, also known as caged or photocaged compounds, have been extensively used to induce a fast concentration jump of a biological effector by a specific light induced chemical bound cleavage. However most caged compounds absorb light in the 300-400 nm region. The UV region presents several disadvantages, especially for biological applications: 1) high-energy UV light has very limited tissue penetration due to high optical scattering and strong absorbance by endogenous chromophores; 2) UV lead to sample over-heating, 3) UV can cause phototoxic or photoallergic reactions.

Visible and especially NIR light looks much more interesting, since it is considerably less harmful to biological materials and can penetrate deeper into tissues, opening the door to new applications of the uncaging concept especially in the field of drug delivery. In this review, 3 strategies leading to photoactivatable molecules or systems with efficient photolytical reactions using red to NIR excitations have been described.

The first strategy is based on the molecular engineering of PPGs leading to a few PPGs activated directly by light of wavelengths above $\sim 600 \mathrm{~nm}$. In particular Coumarinyl, BODIPY and cyanine scaffolds, have extended the uncaging concept in wavelengths up to $500 \mathrm{~nm}$ but the application of this strategy is still limited due to relatively low uncaging efficiencies.

The second strategy is based on the use of two-photon induced photolysis. Several PPGs have been recently developed with extremely efficient TP excitation cross-section for the release of various biological effectors with localized NIR excitation.

Finally, a third strategy, based on the use of indirect photoactivation method was presented. NIR to UV (or visible) upconversion NPs have been recently used to assist photolytical reactions.

We are convinced that all those recent improvements should find significant applications especially in the field of nanomedicine soon [80].

\section{Acknowledgements}

This work was supported by the Université de Strasbourg (IdEx Grant to A.S.) the CNRS and by Grants from the Agence Nationale de la Recherche (Contract No. ANR-13-JSJV-0009-01 and ANR-18-CE090016-01 to A.S.).

Keywords: Photolysis, Uncaging, Two-photon uncaging, Photon-upconversion, Photopharmacology.

Dedicated to Dr. Jacques Vicens. 
J. Chaud, C. Morville, F. Bolze and A. Specht

Laboratoire de Conception et Application de Molécules Bioactives, Équipe de Chimie et Neurobiologie Moléculaire, Faculté de Pharmacie, UMR 7199, Université de Strasbourg / CNRS, 74 route du Rhin, 67401 Illkirch- Graffenstaden Cedex, France e-mail: specht@unistra.fr

\# The first two authors contributed equally

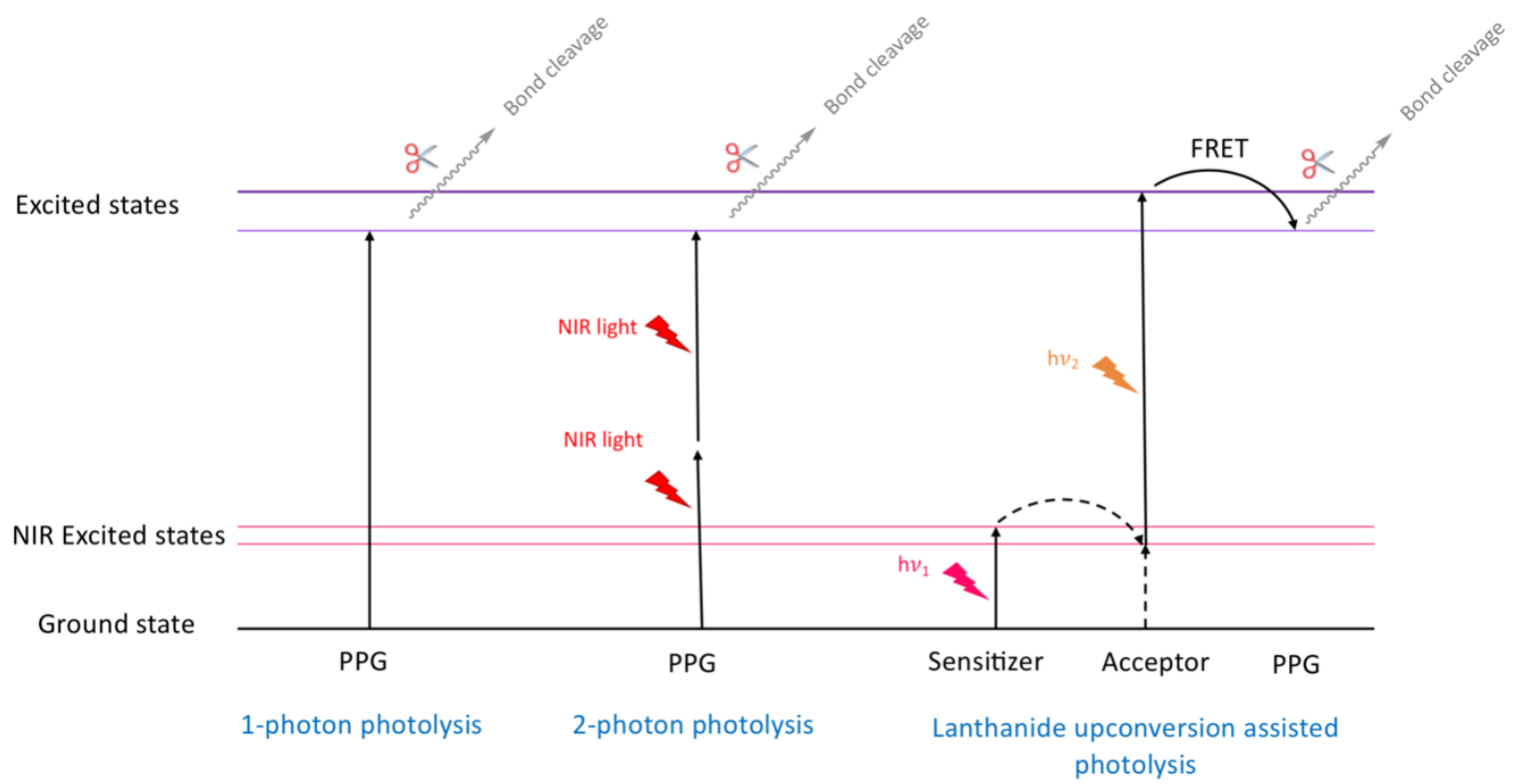

Figure 1: Simplified Jablonski diagrams for One-photon induced, Two-photon induced and Up-Converted assisted photolysis. 
a) o-nitrobenzyl based PPG
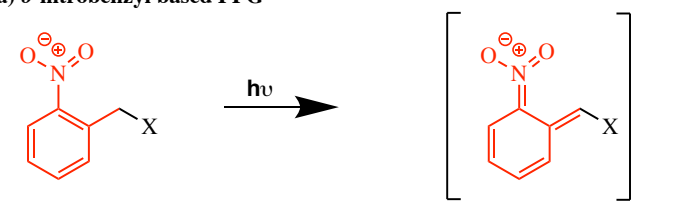

$\longrightarrow$

b) o-nitrophenetyl based PPG<smiles>[X]CCc1ccccc1[N+](=O)[O-]</smiles><smiles>[X]CC=C1C=CC=CC1=[N+]([O-])O</smiles><smiles>CCCC</smiles><smiles>[X]CC=C1C=CC=CC1=[N+]([O-])[O-]</smiles><smiles>[X][CH+]=Cc1ccccc1[N+](=O)[O-]</smiles>

c) Coumarin based PPG<smiles>[X]Cc1cc(=O)oc2ccccc12</smiles>

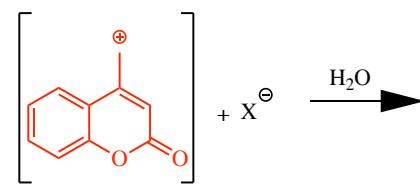<smiles>[Y][IH+]</smiles>

d) BODIPY based PPG<smiles></smiles>

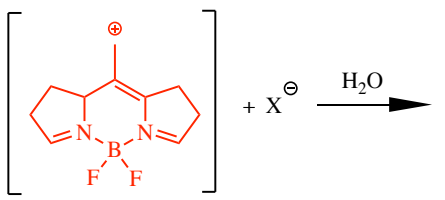

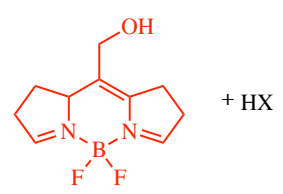

e) Nitroindoline based PPG<smiles>[R]C(=O)N1CCc2cccc([N+](=O)[O-])c21</smiles><smiles>[R]C(=O)O[N+]([O-])=C1C=CC2=CCC3=CCCC2=NCC31</smiles><smiles>[R]C(=O)O[Na]</smiles>

f) Quinoline based PPG<smiles>[X]Cc1ccc2ccccc2n1</smiles><smiles>[X]C(=O)OCc1ccncc1</smiles>

$\mathrm{H}_{2} \mathrm{O}$<smiles>[X][NH2+][OH2+]</smiles>

e) Pyridinium based PPG $\mathrm{O}>^{\mathrm{R}}$<smiles>CC(C)=COCc1ccncc1</smiles>

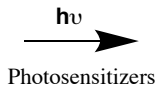<smiles>[R]C(=O)O[Na]</smiles>

Scheme 1 : Photolytical mechanism of NB, NPE, Coumarinyl, BODIPY, Nitroindoline, Quinoline and Pyridinium based PPGs. 


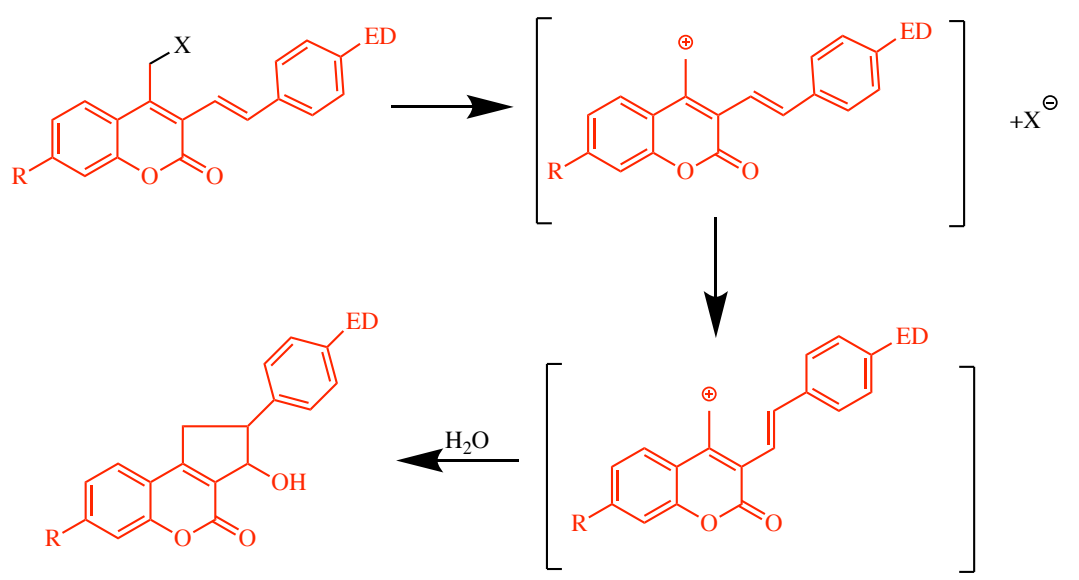

Scheme 2: Styryl moiety effect on the photolysis mechanism of position 3 modified coumarinyl PPGs.

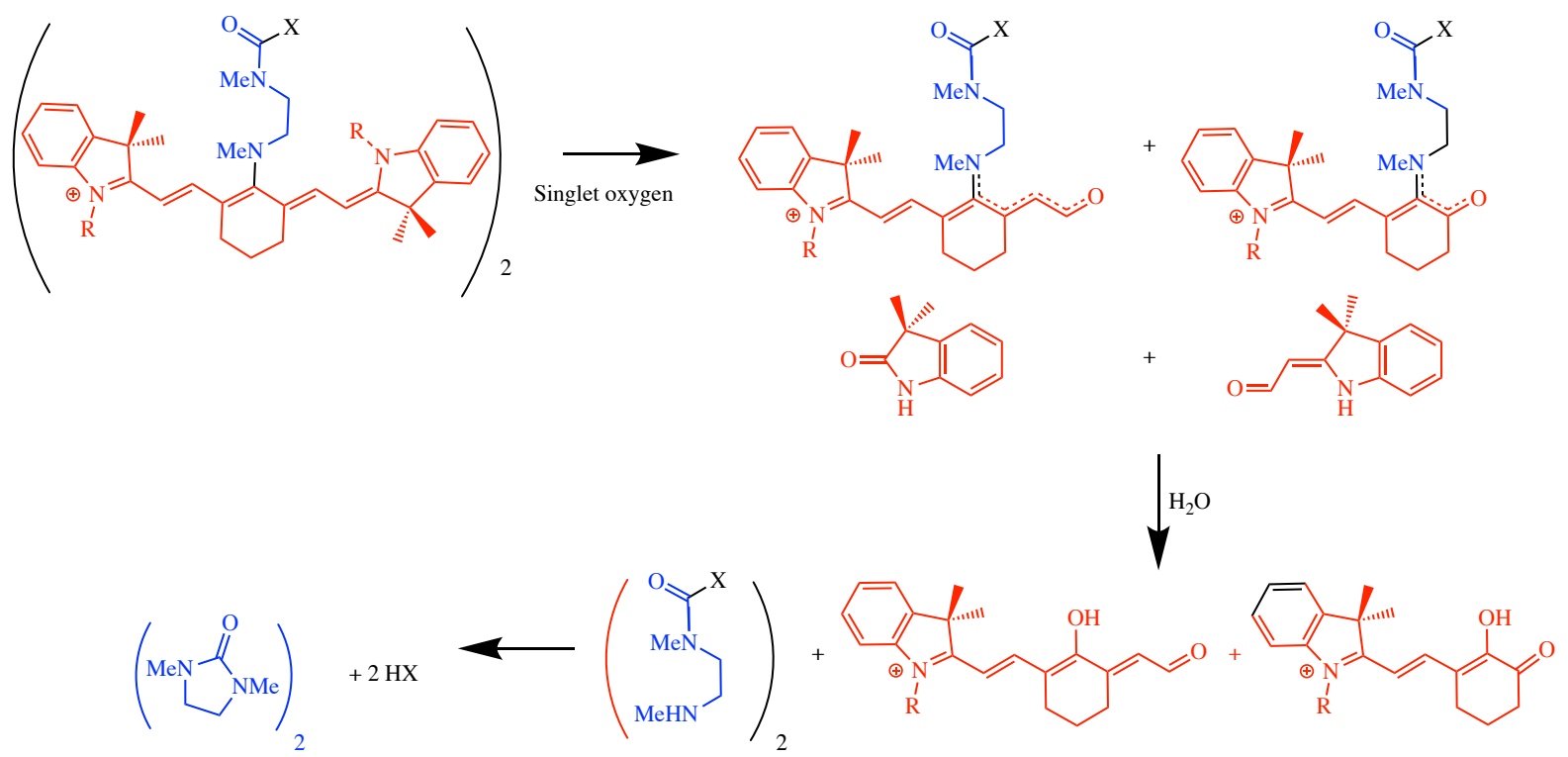

Scheme 3: Cleavage of heptamine cyanine PPG induced by singlet oxygen. 


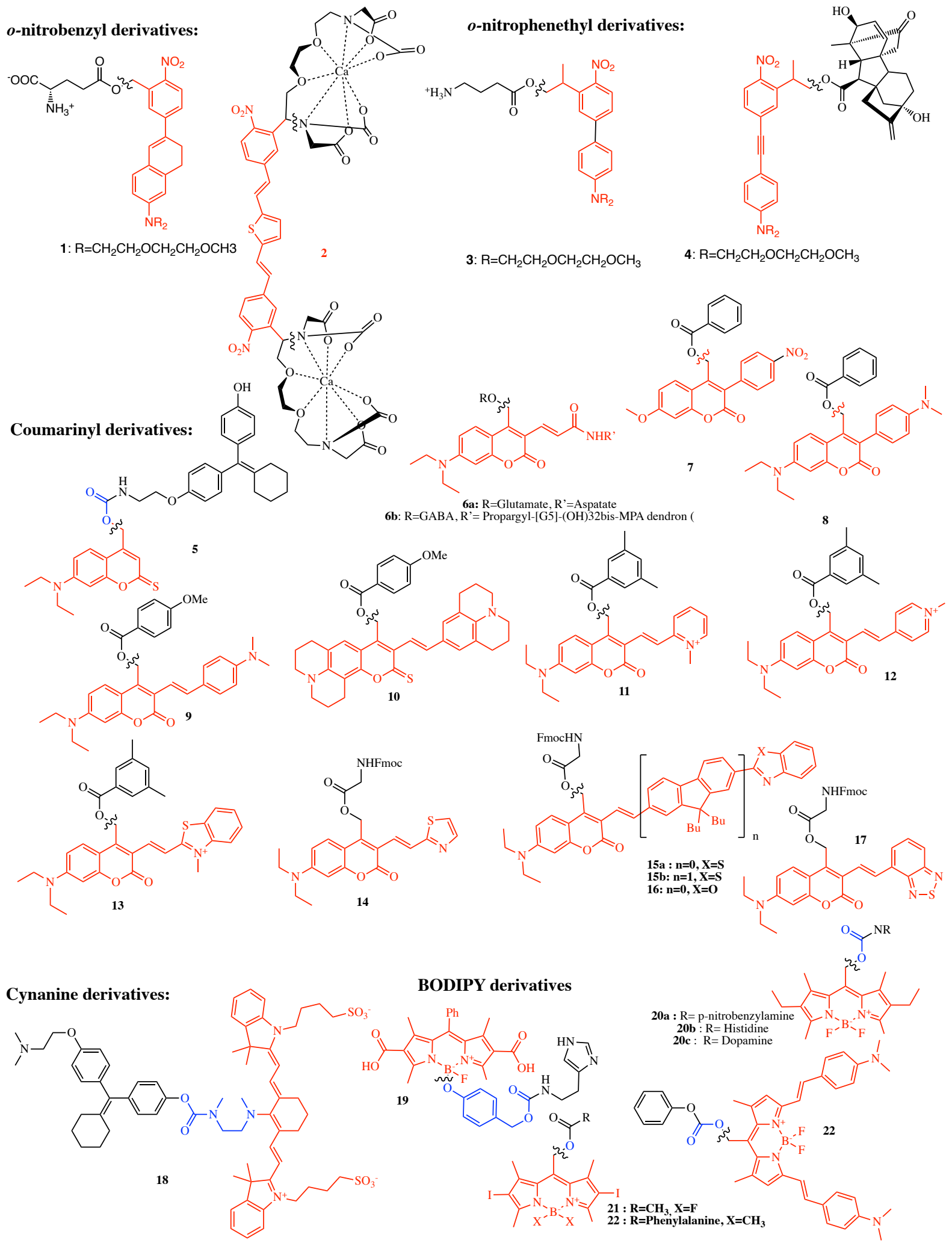

Scheme 4: Chemical structures of one-photon (or TP) sensitive PPGs. 


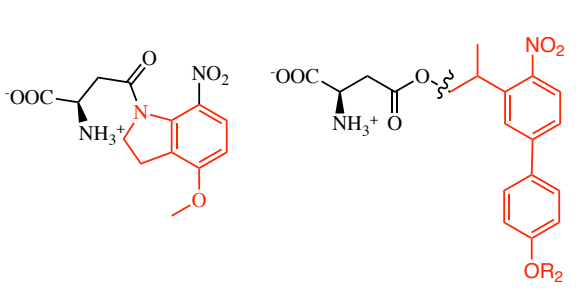

24 25: $\mathrm{R}=\mathrm{CH}_{2} \mathrm{CH}_{2} \mathrm{OCH}_{2} \mathrm{CH}_{2} \mathrm{OCH}_{3}$
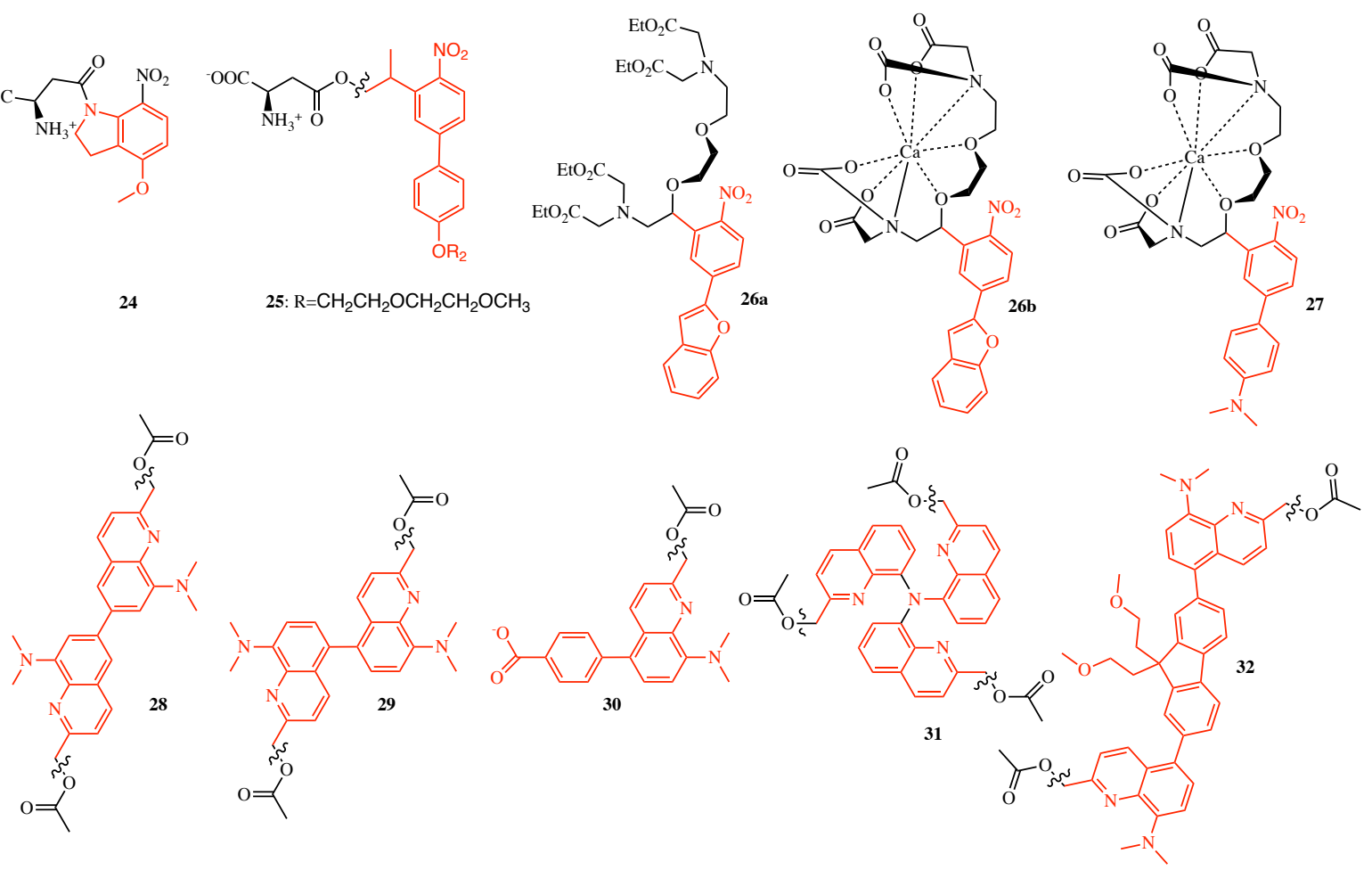

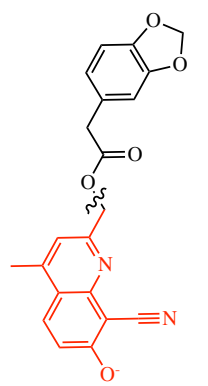

33a

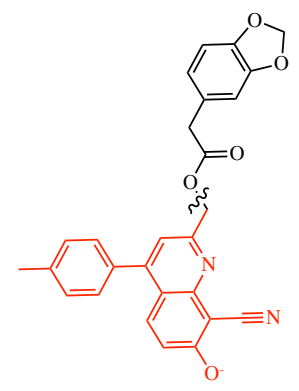

33b

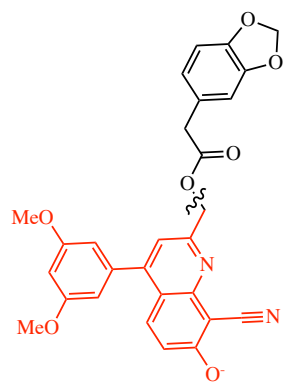

$33 \mathrm{c}$

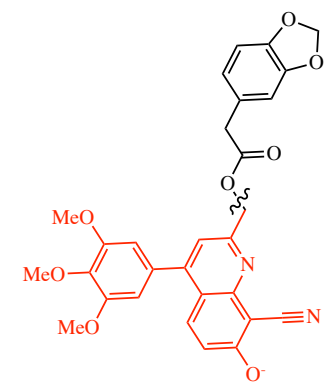

33d

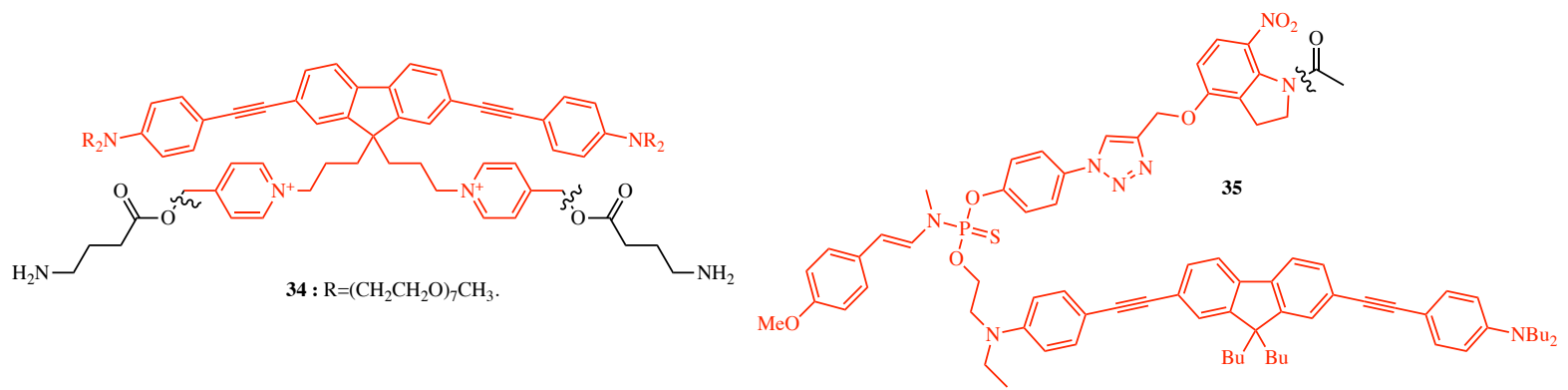

Scheme 5: Chemical structures of TP sensitive PPGs. 


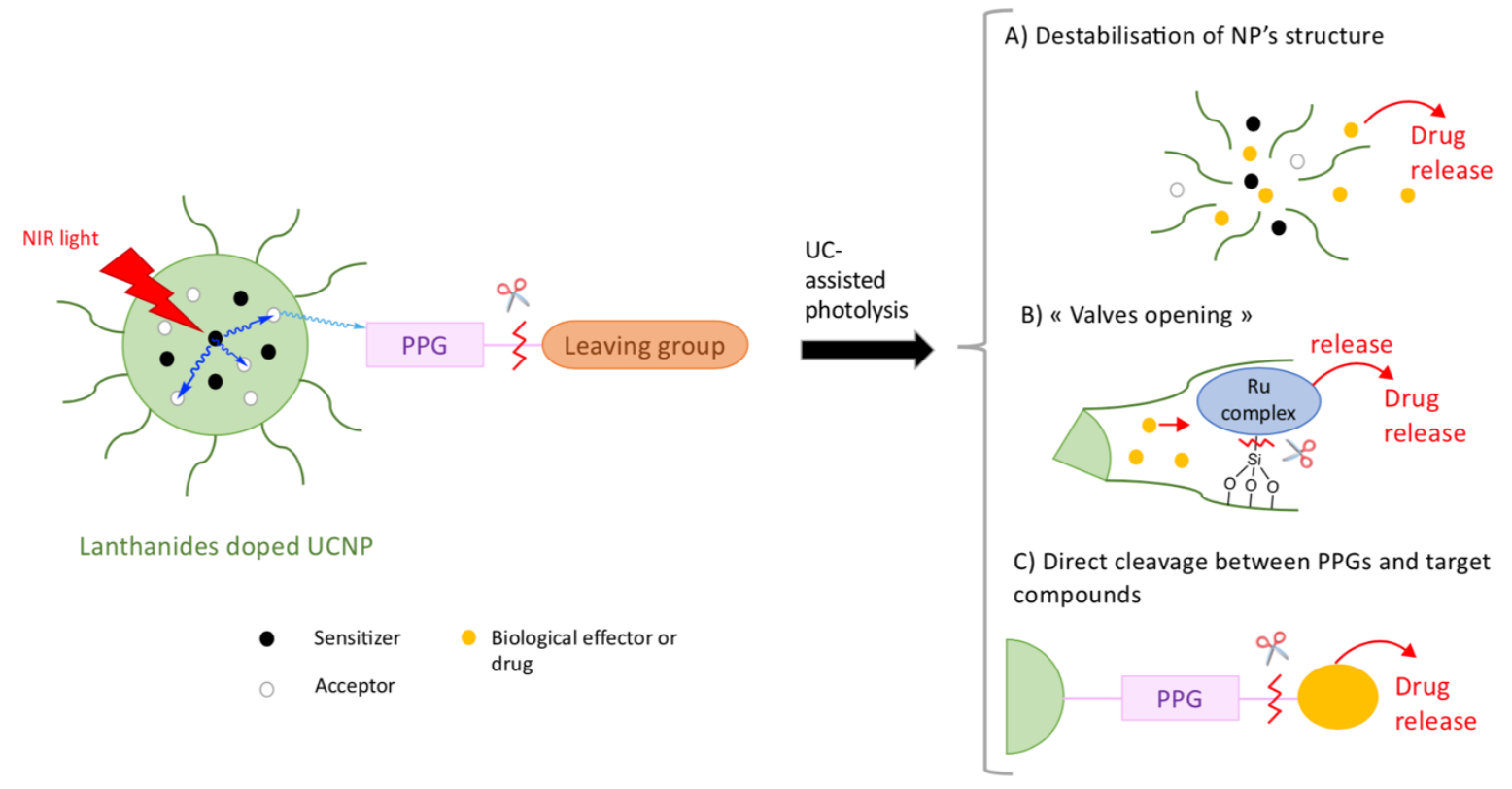

Figure 2: UC assisted photolysis and major applications in the field of nanomedicine. 


\begin{tabular}{|c|c|c|c|c|c|}
\hline Compound & $\lambda_{\max } / \mathrm{nm}$ & $\overline{\Phi_{\mathrm{u}}}$ & $\begin{array}{c}\text { Single photon } \\
\text { Uncaging } \\
\text { efficiency at } \\
\lambda_{\max } \\
\mathrm{M}^{-1} \mathrm{~cm}^{-1}\end{array}$ & $\begin{array}{c}\text { Two-photon } \\
\text { Uncaging } \\
\text { efficiency at } \\
(\lambda / \mathrm{mm}) \\
\text { GM }\end{array}$ & Solvent \\
\hline 1 & 440 & 0.01 & 60 & $\sim 1.2(680)$ & $\mathrm{MeOH}$ \\
\hline 2 & 440 & 0.23 & 15180 & $\sim 80(775)$ & DMSO \\
\hline 3 & 397 & 0.15 & 1125 & $11(800)$ & PBS \\
\hline 4 & 400 & 0.22 & 2500 & $20(800)$ & PBS/DMSO 19/1 \\
\hline 5 & 469 & 0.005 & 135 & l & $\begin{array}{c}\text { ACN/Tris } \\
1 / 1\end{array}$ \\
\hline $\mathbf{6 a}$ & 450 & 0.39 & 16800 & $0.5(900)$ & PBS \\
\hline $6 \mathbf{b}$ & 450 & 0.23 & $\sim 9900$ & $0.5(900)$ & HEPES buffer \\
\hline 7 & 345 & 0.09 & 2045 & $3.4(710)$ & DMSO \\
\hline 8 & 407 & 0.16 & 4560 & $1.1(750)$ & DMSO \\
\hline 9 & 446 & 0.2 & 8200 & $\begin{array}{c}39.6(730) \\
7.3(800)\end{array}$ & $\begin{array}{c}\mathrm{MeOH} / \mathrm{H}_{2} \mathrm{O} \\
9 / 1\end{array}$ \\
\hline 10 & 515 & 0.7 & 17500 & 1 & $\begin{array}{c}\mathrm{MeOH} / \mathrm{H}_{2} \mathrm{O} \\
9 / 1\end{array}$ \\
\hline 11 & 482 & 0.0088 & 260 & $\begin{array}{l}1.54(740) \\
0.52(940)\end{array}$ & $\begin{array}{l}\mathrm{MeOH} \text { (1-photon) } \\
\text { DMSO (2-photon) }\end{array}$ \\
\hline 12 & 493 & 0.0109 & 335 & $\begin{array}{l}3.17(750) \\
1.09(950)\end{array}$ & $\begin{array}{l}\mathrm{MeOH} \text { (1-photon) } \\
\mathrm{DMSO} \text { (2-photon) }\end{array}$ \\
\hline 13 & 538 & 0.0014 & 57 & $1.83(740)$ & $\begin{array}{l}\mathrm{MeOH} \text { (1-photon) } \\
\mathrm{DMSO} \text { (2-photon) }\end{array}$ \\
\hline 14 & 457 & 0.2 & 7800 & $\begin{array}{l}32(950) \\
37(700)\end{array}$ & $\begin{array}{l}\mathrm{CD}_{3} \mathrm{CN} / \mathrm{D}_{2} 09 / 1 \\
\mathrm{DMSO} \text { (2-photon) }\end{array}$ \\
\hline $15 a$ & 472 & 0.08 & 4000 & $\begin{array}{l}30(970) \\
36(710)\end{array}$ & $\begin{array}{c}\mathrm{CD}_{3} \mathrm{CN} / \mathrm{D}_{2} 09 / 1 \\
\mathrm{DMSO} \text { (2-photon) }\end{array}$ \\
\hline $15 b$ & 458 & 0.45 & 18900 & $\begin{array}{c}64(940) \\
442(730)\end{array}$ & $\begin{array}{c}\mathrm{CD}_{3} \mathrm{CN} / \mathrm{D}_{2} 09 / 1 \\
\mathrm{DMSO} \text { (2-photon) }\end{array}$ \\
\hline 16 & 467 & 0.09 & 4500 & $\begin{array}{l}25(970) \\
35(700)\end{array}$ & 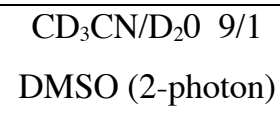 \\
\hline 17 & 472 & $<0.02$ & $<600$ & l & 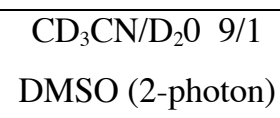 \\
\hline 18 & 690 & l & l & l & l \\
\hline 19 & 502 & $<0.0007$ & $<60$ & l & $\mathrm{CH}_{2} \mathrm{Cl}_{2} / \mathrm{MeOH} 1 / 1$ \\
\hline $20 a$ & 545 & 0.00018 & 7 & I & PBS/ACN 19/1 \\
\hline 21 & 553 & 0.00238 & 117 & I & $\mathrm{MeOH}$ \\
\hline 22 & 537 & 0.32 & 20150 & I & $\mathrm{MeOH}$ \\
\hline 23 & 693 & 0.0014 & 73 & I & $\mathrm{MeOH}$ \\
\hline
\end{tabular}




\begin{tabular}{|c|c|c|c|c|c|}
\hline 24 & 330 & 0.085 & 360 & $0.06(730)$ & PBS \\
\hline 25 & 317 & 0.09 & 890 & $3.2(740)$ & PBS \\
\hline $26 a$ & 364 & 0.3 & 3600 & $16(740)$ & DMSO \\
\hline $26 \mathrm{~b}$ & 365 & 0.3 & 5630 & $20.7(740)$ & $\begin{array}{c}\mathrm{C}_{6} \mathrm{D}_{6} \\
\text { DMSO (2-photon) }\end{array}$ \\
\hline 27 & 403 & $\sim 0.05$ & $\sim 440$ & $7.8(800)$ & $\begin{array}{c}\mathrm{C}_{6} \mathrm{D}_{6} \\
\text { DMSO (2-photon) }\end{array}$ \\
\hline 28 & 341 & 0.093 & 305 & $0.07(730)$ & ACN/Tris: $1 / 1$ \\
\hline 29 & 353 & 0.066 & 180 & $0.4(730)$ & ACN/Tris: $1 / 1$ \\
\hline 30 & 343 & 0.14 & 280 & $2(730)$ & ACN/Tris: $1 / 1$ \\
\hline 31 & 380 & 0.015 & 193 & $0.3(730)$ & ACN/Tris: $1 / 1$ \\
\hline 32 & 321 & 0.015 & 382 & $2.3(730$ & \\
\hline 33a & 367 & 0.88 & 3500 & $1.84(740)$ & $\begin{array}{c}\text { KMOPS pH 7.2/ } \\
\text { CH3CN : 8/2 }\end{array}$ \\
\hline 33b & 373 & 0.74 & $\sim 5000$ & $2.25(740)$ & $\begin{array}{c}\text { KMOPS pH 7.2/ } \\
\mathrm{CH} 3 \mathrm{CN}: 8 / 2\end{array}$ \\
\hline 33c & 374 & 0.81 & $\sim 4800$ & $2.64(740)$ & $\begin{array}{c}\text { KMOPS } \mathrm{pH} 7.2 / \\
\mathrm{CH} 3 \mathrm{CN}: 8 / 2\end{array}$ \\
\hline 33d & 374 & 0.62 & $\sim 5700$ & $2.37(740)$ & $\begin{array}{c}\text { KMOPS pH 7.2/ } \\
\mathrm{CH} 3 \mathrm{CN}: 8 / 2\end{array}$ \\
\hline 34 & 380 & 0.009 & 810 & $10(700)$ & $\mathrm{D}_{2} \mathrm{O}$ \\
\hline 35 & 386 & 0.21 & 1485 & $20(710)$ & $\mathrm{CDCl}_{3}$ \\
\hline
\end{tabular}

Table 1: Photophysical and photochemical properties of recently developed caged compounds.

\section{References}

(1) Brieke, C., Rohrbach, F., Gottschalk, A., Mayer, G., Heckel, A.: Light-Controlled Tools. Angewandte Chemie International Edition 51(34), 8446-8476 (2012). doi:10.1002/anie.201202134.

(2) Klán, P., Šolomek, T., Bochet, C.G., Blanc, A., Givens, R., Rubina, M., Popik, V., Kostikov, A., Wirz, J.: Photoremovable Protecting Groups in Chemistry and Biology: Reaction Mechanisms and Efficacy. Chemical Reviews 113(1), 119-191 (2013). doi:10.1021/cr300177k.

(3) Abou Nakad, E., Chaud, J., Morville, C., Bolze, F., Specht, A.: Monitoring of uncaging processes by designing photolytical reactions. Photochemical \& Photobiological Sciences 19(9), 1122-1133 (2020). doi:10.1039/D0PP00169D.

(4) Weinstain, R., Slanina, T., Kand, D., Klán, P.: Visible-to-NIR-Light Activated Release: From Small Molecules to Nanomaterials. Chemical Reviews 120(24), 13135-13272 (2020). doi:10.1021/acs.chemrev.0c00663.

(5) Lin, Y., Mazo, M.M., Skaalure, S.C., Thomas, M.R., Schultz, S.R., Stevens, M.M.: Activatable cellbiomaterial interfacing with photo-caged peptides. Chemical Science 10(4), 1158-1167 (2019). doi:10.1039/C8SC04725A.

(6) Gautier, A., Gauron, C., Volovitch, M., Bensimon, D., Jullien, L., Vriz, S.: How to control proteins with light in living systems. Nat Chem Biol 10(7), 533-541 (2014). doi:10.1038/nchembio.1534.

(7) Courtney, T., Deiters, A.: Recent advances in the optical control of protein function through genetic code expansion. Current Opinion in Chemical Biology 46, 99-107 (2018). doi:https://doi.org/10.1016/j.cbpa.2018.07.011.

(8) Ruble, B.K., Yeldell, S.B., Dmochowski, I.J.: Caged oligonucleotides for studying biological systems. $\begin{array}{llllll}\text { Journal of Inorganic } & \text { Biochemistry } & 18015) \text {. }\end{array}$ doi:https://doi.org/10.1016/j.jinorgbio.2015.03.010. 
(9) Ikeda, M., Kabumoto, M.: Chemically Caged Nucleic Acids. Chemistry Letters 46(5), 634-640 (2017). doi:10.1246/cl.161063.

(10)Paoletti, P., Ellis-Davies, G.C.R., Mourot, A.: Optical control of neuronal ion channels and receptors. Nature Reviews Neuroscience 20(9), 514-532 (2019). doi:10.1038/s41583-019-0197-2.

(11)Höglinger, D., Nadler, A., Schultz, C.: Caged lipids as tools for investigating cellular signaling. Biochimica et Biophysica Acta (BBA) - Molecular and Cell Biology of Lipids 1841(8), 1085-1096 (2014). doi:https://doi.org/10.1016/j.bbalip.2014.03.012.

(12) Ankenbruck, N., Courtney, T., Naro, Y., Deiters, A.: Optochemical Control of Biological Processes in Cells and Animals. Angew Chem Int Ed Engl 57(11), 2768-2798 (2018). doi:10.1002/anie.201700171.

(13) Silva, J.M., Silva, E., Reis, R.L.: Light-triggered release of photocaged therapeutics - Where are we now? Journal of Controlled Release 298, 154-176 (2019). doi:https://doi.org/10.1016/j.jconrel.2019.02.006.

(14)Zhang, Y., Xu, C., Yang, X., Pu, K.: Photoactivatable Protherapeutic Nanomedicine for Cancer. Advanced Materials 32(34), 2002661 (2020). doi:https://doi.org/10.1002/adma.202002661.

(15) Weissleder, R.: A clearer vision for in vivo imaging. Nature Biotechnology 19(4), 316-317 (2001). doi:10.1038/86684.

(16) Wäldchen, S., Lehmann, J., Klein, T., van de Linde, S., Sauer, M.: Light-induced cell damage in live-cell super-resolution microscopy. Scientific Reports 5(1), 15348 (2015). doi:10.1038/srep15348.

(17)Kaplan, J.H., Forbush, B., Hoffman, J.F.: Rapid photolytic release of adenosine 5'-triphosphate from a protected analog: utilization by the sodium:potassium pump of human red blood cell ghosts. Biochemistry 17(10), 1929-1935 (1978). doi:10.1021/bi00603a020.

(18)Engels, J., Schlaeger, E.J.: Synthesis, structure, and reactivity of adenosine cyclic 3',5'-phosphatebenzyltriesters. Journal of Medicinal Chemistry 20(7), 907-911 (1977). doi:10.1021/jm00217a008.

(19) Aujard, I., Benbrahim, C., Gouget, M., Ruel, O., Baudin, J.-B., Neveu, P., Jullien, L.: o-Nitrobenzyl Photolabile Protecting Groups with Red-Shifted Absorption: Syntheses and Uncaging Cross-Sections for One- and Two-Photon Excitation. Chemistry - A European Journal 12(26), 6865-6879 (2006). doi:https://doi.org/10.1002/chem.200501393.

(20) Boinapally, S., Huang, B., Abe, M., Katan, C., Noguchi, J., Watanabe, S., Kasai, H., Xue, B., Kobayashi, T.: Caged Glutamates with $\pi$-Extended 1,2-Dihydronaphthalene Chromophore: Design, Synthesis, TwoPhoton Absorption Property, and Photochemical Reactivity. The Journal of Organic Chemistry 79(17), $7822-7830$ (2014). doi:10.1021/jo501425p.

(21) Agarwal, H.K., Janicek, R., Chi, S.-H., Perry, J.W., Niggli, E., Ellis-Davies, G.C.R.: Calcium Uncaging with Visible Light. Journal of the American Chemical Society 138(11), 3687-3693 (2016). doi:10.1021/jacs.5b11606.

(22)Donato, L., Mourot, A., Davenport, C.M., Herbivo, C., Warther, D., Léonard, J., Bolze, F., Nicoud, J.-F., Kramer, R.H., Goeldner, M., Specht, A.: Water-Soluble, Donor-Acceptor Biphenyl Derivatives in the 2(o-Nitrophenyl)propyl Series: Highly Efficient Two-Photon Uncaging of the Neurotransmitter $\gamma$ Aminobutyric Acid at $\lambda=800 \mathrm{~nm}$. Angewandte Chemie International Edition 51(8), 1840-1843 (2012). doi:https://doi.org/10.1002/anie.201106559.

(23) Schelkle, K.M., Griesbaum, T., Ollech, D., Becht, S., Buckup, T., Hamburger, M., Wombacher, R.: LightInduced Protein Dimerization by One- and Two-Photon Activation of Gibberellic Acid Derivatives in Living Cells. Angewandte Chemie International Edition 54(9), 2825-2829 (2015). doi:https://doi.org/10.1002/anie.201409196.

(24)Hagen, V., Frings, S., Wiesner, B., Helm, S., Kaupp, U.B., Bendig, J.: [7-(Dialkylamino)coumarin-4yl]methyl-Caged Compounds as Ultrafast and Effective Long-Wavelength Phototriggers of 8Bromo$\begin{array}{lllll}\text { Substituted Cyclic } & \text { Nucleotides. }\end{array}$ doi:https://doi.org/10.1002/cbic.200300561

(25) Givens, R.S., Rubina, M., Wirz, J.: Applications of p-hydroxyphenacyl (pHP) and coumarin-4-ylmethyl photoremovable protecting groups. Photochemical \& Photobiological Sciences 11(3), 472-488 (2012). doi:10.1039/C2PP05399C.

(26)Fournier, L., Aujard, I., Le Saux, T., Maurin, S., Beaupierre, S., Baudin, J.-B., Jullien, L.: Coumarinylmethyl Caging Groups with Redshifted Absorption. Chemistry - A European Journal 19(51), 17494-17507 (2013). doi:https://doi.org/10.1002/chem.201302630.

(27)Fournier, L., Gauron, C., Xu, L., Aujard, I., Le Saux, T., Gagey-Eilstein, N., Maurin, S., Dubruille, S., Baudin, J.-B., Bensimon, D., Volovitch, M., Vriz, S., Jullien, L.: A Blue-Absorbing Photolabile Protecting Group for in Vivo Chromatically Orthogonal Photoactivation. ACS Chemical Biology 8(7), 1528-1536 (2013). doi:10.1021/cb400178m.

(28)Olson, J.P., Kwon, H.-B., Takasaki, K.T., Chiu, C.Q., Higley, M.J., Sabatini, B.L., Ellis-Davies, G.C.R.: Optically Selective Two-Photon Uncaging of Glutamate at $900 \mathrm{~nm}$. Journal of the American Chemical Society 135(16), 5954-5957 (2013). doi:10.1021/ja4019379. 
(29)Richers, M.T., Amatrudo, J.M., Olson, J.P., Ellis-Davies, G.C.R.: Cloaked Caged Compounds: Chemical Probes for Two-Photon Optoneurobiology. Angewandte Chemie International Edition 56(1), 193-197 (2017). doi:https://doi.org/10.1002/anie.201609269.

(30) Chitose, Y., Abe, M., Furukawa, K., Katan, C.: Design, Synthesis, and Reaction of $\pi$-Extended Coumarinbased New Caged Compounds with Two-photon Absorption Character in the Near-IR Region. Chemistry Letters 45(10), 1186-1188 (2016). doi:10.1246/cl.160586

(31)Chitose, Y., Abe, M., Furukawa, K., Lin, J.-Y., Lin, T.-C., Katan, C.: Design and Synthesis of a Caged Carboxylic Acid with a Donor- $\pi-$ Donor Coumarin Structure: One-photon and Two-photon Uncaging Reactions Using Visible and Near-Infrared Lights. Organic Letters 19(10), 2622-2625 (2017). doi:10.1021/acs.orglett.7b00957.

(32)Lin, Q., Yang, L., Wang, Z., Hua, Y., Zhang, D., Bao, B., Bao, C., Gong, X., Zhu, L.: Coumarin Photocaging Groups Modified with an Electron-Rich Styryl Moiety at the 3-Position: Long-Wavelength Excitation, Rapid Photolysis, and Photobleaching. Angewandte Chemie International Edition 57(14), 3722-3726 (2018). doi:https://doi.org/10.1002/anie.201800713.

(33)Bojtár, M., Kormos, A., Kis-Petik, K., Kellermayer, M., Kele, P.: Green-Light Activatable, WaterSoluble Red-Shifted Coumarin Photocages. Organic Letters 21(23), 9410-9414 (2019). doi:10.1021/acs.orglett.9b03624.

(34)Klausen, M., Dubois, V., Clermont, G., Tonnelé, C., Castet, F., Blanchard-Desce, M.: Dual-wavelength efficient two-photon photorelease of glycine by $\pi$-extended dipolar coumarins. Chemical Science 10(15), 4209-4219 (2019). doi:10.1039/C9SC00148D.

(35) Gorka, A.P., Nani, R.R., Zhu, J., Mackem, S., Schnermann, M.J.: A Near-IR Uncaging Strategy Based on Cyanine Photochemistry. Journal of the American Chemical Society 136(40), 14153-14159 (2014). doi:10.1021/ja5065203.

(36)Umeda, N., Takahashi, H., Kamiya, M., Ueno, T., Komatsu, T., Terai, T., Hanaoka, K., Nagano, T., Urano, Y.: Boron Dipyrromethene As a Fluorescent Caging Group for Single-Photon Uncaging with Long-Wavelength Visible Light. ACS Chemical Biology 9(10), 2242-2246 (2014). doi:10.1021/cb500525p.

(37) Rubinstein, N., Liu, P., Miller, E.W., Weinstain, R.: meso-Methylhydroxy BODIPY: a scaffold for photolabile protecting groups. Chemical Communications 51(29), 6369-6372 (2015). doi:10.1039/C5CC00550G.

(38) Goswami, P.P., Syed, A., Beck, C.L., Albright, T.R., Mahoney, K.M., Unash, R., Smith, E.A., Winter, A.H.: BODIPY-Derived Photoremovable Protecting Groups Unmasked with Green Light. Journal of the American Chemical Society 137(11), 3783-3786 (2015). doi:10.1021/jacs.5b01297.

(39) Slanina, T., Shrestha, P., Palao, E., Kand, D., Peterson, J.A., Dutton, A.S., Rubinstein, N., Weinstain, R., Winter, A.H., Klán, P.: In Search of the Perfect Photocage: Structure-Reactivity Relationships in mesoMethyl BODIPY Photoremovable Protecting Groups. Journal of the American Chemical Society 139(42), 15168-15175 (2017). doi:10.1021/jacs.7b08532.

(40)Peterson, J.A., Wijesooriya, C., Gehrmann, E.J., Mahoney, K.M., Goswami, P.P., Albright, T.R., Syed, A., Dutton, A.S., Smith, E.A., Winter, A.H.: Family of BODIPY Photocages Cleaved by Single Photons of Visible/Near-Infrared Light. Journal of the American Chemical Society 140(23), 7343-7346 (2018). doi:10.1021/jacs.8b04040.

(41)Rodat, T., Krebs, M., Döbber, A., Jansen, B., Steffen-Heins, A., Schwarz, K., Peifer, C.: Restricted suitability of BODIPY for caging in biological applications based on singlet oxygen generation. Photochemical \& Photobiological Sciences 19(10), 1319-1325 (2020). doi:10.1039/D0PP00097C.

(42)Furuta, T., Wang, S.S.-H., Dantzker, J.L., Dore, T.M., Bybee, W.J., Callaway, E.M., Denk, W., Tsien, R.Y.: Brominated 7-hydroxycoumarin-4-ylmethyls: Photolabile protecting groups with biologically useful cross-sections for two photon photolysis. Proceedings of the National Academy of Sciences 96(4), 1193-1200 (1999). doi:10.1073/pnas.96.4.1193.

(43) Bort, G., Gallavardin, T., Ogden, D., Dalko, P.I.: From One-Photon to Two-Photon Probes: "Caged" Compounds, Actuators, and Photoswitches. Angewandte Chemie International Edition 52(17), 45264537 (2013). doi:https://doi.org/10.1002/anie.201204203.

(44)Piant, S., Bolze, F., Specht, A.: - Two-photon uncaging, from neuroscience to materials. Optical Materials Express 6(5), 1679-1691 (2016). doi:10.1364/OME.6.001679.

(45) Abe, M., Chitose, Y., Jakkampudi, S., Thuy, P.T.T., Lin, Q., Van, B.T., Yamada, A., Oyama, R., Sasaki, M., Katan, C.: Design and Synthesis of Two-Photon Responsive Chromophores for Near-Infrared LightInduced Uncaging Reactions. Synthesis 49(15), 3337-3346 (2017).

(46)Ellis-Davies, G.C.R.: Two-Photon Uncaging of Glutamate. Frontiers in Synaptic Neuroscience 10(48) (2019). doi:10.3389/fnsyn.2018.00048. 
(47)Matsuzaki, M., Ellis-Davies, G.C.R., Nemoto, T., Miyashita, Y., Iino, M., Kasai, H.: Dendritic spine geometry is critical for AMPA receptor expression in hippocampal CA1 pyramidal neurons. Nature Neuroscience 4(11), 1086-1092 (2001). doi:10.1038/nn736.

(48)Lovett-Barron, M., Turi, G.F., Kaifosh, P., Lee, P.H., Bolze, F., Sun, X.H., Nicoud, J.F., Zemelman, B.V., Sternson, S.M., Losonczy, A.: Regulation of neuronal input transformations by tunable dendritic inhibition. Nature neuroscience 15(3), 423-430, s421-423 (2012). doi:10.1038/nn.3024.

(49) Komori, N., Jakkampudi, S., Motoishi, R., Abe, M., Kamada, K., Furukawa, K., Katan, C., Sawada, W., Takahashi, N., Kasai, H., Xue, B., Kobayashi, T.: Design and synthesis of a new chromophore, 2-(4nitrophenyl)benzofuran, for two-photon uncaging using near-IR light. Chemical Communications 52(2), 331-334 (2016). doi:10.1039/C5CC07664A

(50) Jakkampudi, S., Abe, M., Komori, N., Takagi, R., Furukawa, K., Katan, C., Sawada, W., Takahashi, N., Kasai, H.: Design and Synthesis of a 4-Nitrobromobenzene Derivative Bearing an Ethylene Glycol Tetraacetic Acid Unit for a New Generation of Caged Calcium Compounds with Two-Photon Absorption Properties in the Near-IR Region and Their Application in Vivo. ACS Omega 1(2), 193-201 (2016). doi:10.1021/acsomega.6b00119.

(51) Dunkel, P., Tran, C., Gallavardin, T., Dhimane, H., Ogden, D., Dalko, P.I.: Quinoline-derived two-photon sensitive quadrupolar probes. Organic \& Biomolecular Chemistry 12(48), 9899-9908 (2014). doi:10.1039/C4OB01551G.

(52)Tran, C., Gallavardin, T., Petit, M., Slimi, R., Dhimane, H., Blanchard-Desce, M., Acher, F.C., Ogden, D., Dalko, P.I.: Two-Photon "Caging” Groups: Effect of Position Isomery on the Photorelease Properties of Aminoquinoline-Derived Photolabile Protecting Groups. Organic Letters 17(3), $402-405$ (2015). doi:10.1021/ol5035035.

(53)Dunkel, P., Petit, M., Dhimane, H., Blanchard-Desce, M., Ogden, D., Dalko, P.I.: Quinoline-Derived Two-Photon-Sensitive Octupolar Probes. ChemistryOpen 6(5), 660-667 (2017). doi:https://doi.org/10.1002/open.201700097.

(54)Tran, C., Berqouch, N., Dhimane, H., Clermont, G., Blanchard-Desce, M., Ogden, D., Dalko, P.I.: Quinoline-Derived Two-Photon Sensitive Quadrupolar Probes. Chemistry - A European Journal 23(8), 1860-1868 (2017). doi:https://doi.org/10.1002/chem.201604500.

(55)Davis, M.J., Kragor, C.H., Reddie, K.G., Wilson, H.C., Zhu, Y., Dore, T.M.: Substituent Effects on the Sensitivity of a Quinoline Photoremovable Protecting Group to One- and Two-Photon Excitation. The Journal of Organic Chemistry 74(4), 1721-1729 (2009). doi:10.1021/jo802658a.

(56)Hennig, A.-L.K., Deodato, D., Asad, N., Herbivo, C., Dore, T.M.: Two-Photon Excitable Photoremovable Protecting Groups Based on the Quinoline Scaffold for Use in Biology. The Journal of Organic Chemistry 85(2), 726-744 (2020). doi:10.1021/acs.joc.9b02780.

(57) Specht, A., Bolze, F., Donato, L., Herbivo, C., Charon, S., Warther, D., Gug, S., Nicoud, J.-F., Goeldner, M.: The donor-acceptor biphenyl platform: A versatile chromophore for the engineering of highly efficient two-photon sensitive photoremovable protecting groups. Photochemical \& Photobiological Sciences 11(3), 578-586 (2012). doi:10.1039/C2PP05360H.

(58)Klausen, M., Dubois, V., Verlhac, J.-B., Blanchard-Desce, M.: Tandem Systems for Two-Photon Uncaging of Bioactive Molecules. ChemPlusChem 84(6), 589-598 (2019). doi:https://doi.org/10.1002/cplu.201900139.

(59) Korzycka, K.A., Bennett, P.M., Cueto-Diaz, E.J., Wicks, G., Drobizhev, M., Blanchard-Desce, M., Rebane, A., Anderson, H.L.: Two-photon sensitive protecting groups operating via intramolecular electron transfer: uncaging of GABA and tryptophan. Chemical Science 6(4), 2419-2426 (2015). doi:10.1039/C4SC03775H.

(60) Cueto Diaz, E., Picard, S., Klausen, M., Hugues, V., Pagano, P., Genin, E., Blanchard-Desce, M.: Cooperative Veratryle and Nitroindoline Cages for Two-Photon Uncaging in the NIR. Chemistry - A European Journal 22(31), 10848-10859 (2016). doi:https://doi.org/10.1002/chem.201601109.

(61) Auzel, F.: Upconversion and Anti-Stokes Processes with f and d Ions in Solids. Chemical Reviews 104(1), 139-174 (2004). doi:10.1021/cr020357g.

(62)Zhou, J., Liu, Q., Feng, W., Sun, Y., Li, F.: Upconversion Luminescent Materials: Advances and Applications. Chemical Reviews 115(1), 395-465 (2015). doi:10.1021/cr400478f.

(63)Cohen, B.E.: Beyond fluorescence. Nature 467(7314), 407-408 (2010). doi:10.1038/467407a.

(64) Heer, S., Kömpe, K., Güdel, H.-U., Haase, M.: Highly Efficient Multicolour Upconversion Emission in Transparent Colloids of Lanthanide-Doped NaYF4 Nanocrystals. Advanced Materials 16(23-24), 21022105 (2004). doi:https://doi.org/10.1002/adma.200400772.

(65) Yi, G., Lu, H., Zhao, S., Ge, Y., Yang, W., Chen, D., Guo, L.-H.: Synthesis, Characterization, and Biological Application of Size-Controlled Nanocrystalline NaYF4:Yb,Er Infrared-to-Visible UpConversion Phosphors. Nano Letters 4(11), 2191-2196 (2004). doi:10.1021/n1048680h. 
(66) Carling, C.-J., Nourmohammadian, F., Boyer, J.-C., Branda, N.R.: Remote-Control Photorelease of Caged Compounds Using Near-Infrared Light and Upconverting Nanoparticles. Angewandte Chemie International Edition 49(22), 3782-3785 (2010). doi:https://doi.org/10.1002/anie.201000611.

(67) Yang, Y., Shao, Q., Deng, R., Wang, C., Teng, X., Cheng, K., Cheng, Z., Huang, L., Liu, Z., Liu, X., Xing, B.: In Vitro and In Vivo Uncaging and Bioluminescence Imaging by Using Photocaged Upconversion Nanoparticles. Angewandte Chemie International Edition 51(13), 3125-3129 (2012). doi:https://doi.org/10.1002/anie.201107919.

(68) Yan, B., Boyer, J.-C., Branda, N.R., Zhao, Y.: Near-Infrared Light-Triggered Dissociation of Block Copolymer Micelles Using Upconverting Nanoparticles. Journal of the American Chemical Society 133(49), 19714-19717 (2011). doi:10.1021/ja209793b.

(69) Yan, B., Boyer, J.-C., Habault, D., Branda, N.R., Zhao, Y.: Near Infrared Light Triggered Release of Biomacromolecules from Hydrogels Loaded with Upconversion Nanoparticles. Journal of the American Chemical Society 134(40), 16558-16561 (2012). doi:10.1021/ja308876j.

(70) He, S., Krippes, K., Ritz, S., Chen, Z., Best, A., Butt, H.-J., Mailänder, V., Wu, S.: Ultralow-intensity near-infrared light induces drug delivery by upconverting nanoparticles. Chemical Communications 51(2), 431-434 (2015). doi:10.1039/C4CC07489K.

(71)Chien, Y.-H., Chou, Y.-L., Wang, S.-W., Hung, S.-T., Liau, M.-C., Chao, Y.-J., Su, C.-H., Yeh, C.-S.: Near-Infrared Light Photocontrolled Targeting, Bioimaging, and Chemotherapy with Caged Upconversion Nanoparticles in Vitro and in Vivo. ACS Nano 7(10), 8516-8528 (2013). doi:10.1021/nn402399m.

(72)Zhao, L., Peng, J., Huang, Q., Li, C., Chen, M., Sun, Y., Lin, Q., Zhu, L., Li, F.: Near-Infrared Photoregulated Drug Release in Living Tumor Tissue via Yolk-Shell Upconversion Nanocages. Advanced Functional Materials 24(3), 363-371 (2014). doi:https://doi.org/10.1002/adfm.201302133.

(73)Li, W., Wang, J., Ren, J., Qu, X.: Near-Infrared Upconversion Controls Photocaged Cell Adhesion. Journal of the American Chemical Society 136(6), 2248-2251 (2014). doi:10.1021/ja412364m.

(74) Chen, Z., He, S., Butt, H.-J., Wu, S.: Photon Upconversion Lithography: Patterning of Biomaterials Using Near-Infrared Light. Advanced Materials 27(13), 2203-2206 (2015). doi:https://doi.org/10.1002/adma.201405933

(75) Viger, M.L., Grossman, M., Fomina, N., Almutairi, A.: Low Power Upconverted Near-IR Light for Efficient Polymeric Nanoparticle Degradation and Cargo Release. Advanced Materials 25(27), 37333738 (2013). doi:https://doi.org/10.1002/adma.201300902.

(76) Ruggiero, E., Habtemariam, A., Yate, L., Mareque-Rivas, J.C., Salassa, L.: Near infrared photolysis of a $\mathrm{Ru}$ polypyridyl complex by upconverting nanoparticles. Chemical Communications 50(14), 1715-1718 (2014). doi:10.1039/C3CC47601D.

(77)Chen, Z., Xiong, Y., Etchenique, R., Wu, S.: Manipulating pH using near-infrared light assisted by upconverting nanoparticles. Chemical Communications 52(97), 13959-13962 (2016). doi:10.1039/C6CC05287H.

(78) Askes, S.H.C., Bahreman, A., Bonnet, S.: Activation of a Photodissociative Ruthenium Complex by Triplet-Triplet Annihilation Upconversion in Liposomes. Angewandte Chemie International Edition 53(4), 1029-1033 (2014). doi:https://doi.org/10.1002/anie.201309389.

(79) Huang, L., Zhao, Y., Zhang, H., Huang, K., Yang, J., Han, G.: Expanding Anti-Stokes Shifting in Triplet-Triplet Annihilation Upconversion for In Vivo Anticancer Prodrug Activation. Angewandte Chemie International Edition 56(46), 14400-14404 (2017). doi:https://doi.org/10.1002/anie.201704430.

(80) Zhao, W., Zhao, Y., Wang, Q., Liu, T., Sun, J., Zhang, R.: Remote Light-Responsive Nanocarriers for Controlled Drug Delivery: Advances and Perspectives. Small 15(45), 1903060 (2019). doi:https://doi.org/10.1002/smll.201903060. 